\title{
DIRAS3 wt Allele
}

National Cancer Institute

\section{Source}

National Cancer Institute. DIRAS3 wt Allele. NCI Thesaurus. Code C52535.

Human DIRAS3 wild-type allele is located in the vicinity of $1 \mathrm{p} 31$ and is approximately $6 \mathrm{~kb}$

in length. This allele, which encodes GTP-binding protein Di-Ras3, is involved in cellular growth suppression. 